\title{
Conceptions and Misconceptions of Instructors Pertaining to Their Roles and Competencies in Distance Education: A Qualitative Case Study
}

\author{
Mehmet Kara* \\ Department of Computer Technology, Amasya University, Amasya, Turkey
}

Volkan Kukul

Department of Computer Education and Instructional Technology, Amasya University, Amasya, Turkey

\section{Recep Çakır}

Department of Computer Education and Instructional Technology, Amasya University, Amasya, Turkey

Article history

Received:

05.09.2018

Received in revised form: 22.10.2018

Accepted:

23.10.2018

Key words:

Distance Education, Instructor Roles, Instructor Competencies, Conceptions, Misconceptions
The purpose of this study is to investigate the conceptions and misconceptions of instructors pertaining to their roles and competencies in distance education. Case study research design was adopted within the study. The participants, nine instructors in a public university delivering the courses in fully distance programs, was selected by using typical case sampling strategy. The data were collected through semi-structured interviews and observations on distance courses. The collected data were analysed through constant comparison analysis. The qualitative analysis revealed instructors' conceptions of roles, competencies, and misconceptions in distance education. Roles included planning and delivery. Planning sub-theme covered the roles of environmental / technical planning and instructional design. Delivery sub-theme covered the roles of lecturing, evaluation, guidance, motivation, and material development. Participants' conceptions of competencies included ICT competency, communication skills, and subject expertise. Finally, the study findings identified the misconceptions of the instructors. The identified misconceptions were identified as use of the same materials with face-to-face education, sufficient materials, lack of role for interaction among students, ineffectiveness of distance education, having the same roles with face-to-face education, and impossibility of distance collaboration among students. The findings imply that the instructors' conceptions of roles and competencies are based on their experience in both face-to-face and distance education and this base unsurprisingly caused misconceptions regarding teaching in distance education. 


\section{Introduction}

Distance education is independent of time and place, and often teachers and students are at different times and places to participate in teaching process. It is a theoretical and systematic education system in which students, teachers and teaching materials come together through different communication technologies (Moore, \& Kearsley, 2004). The use of distance education system increases proportionally with developing technology. Distance education, which is now a necessity of the age, is a system preferred for people of all ages to be educated without having to go to an educational institution. Distance education provides people with many advantages, some of them are the followings:

- Getting flexible education as independent of time and place

- Education according to individual differences

- To be able to learn according to their own learning speed

- Rich with multimedia support and therefore more efficient and effective education

- To be able to learn from subject experts

- Providing lifelong learning

- Contribution to equality of opportunity in education (Umurhan, 2008; Kaya, 2002).

Historically, distance education, which began with correspondence education in the United States in the 1800s, has improved and provided the opportunity to reach large audiences with the development of technology. Especially with the spread of the internet, there have been innovations in distance education processes (Gülbahar, 2009). According to Gülbahar (2009) distance education processes take place in different places, require special instructional design and techniques, communicate with different technologies and require specific institutional and managerial structuring.

In recent years, the number of distance education classes and the number of students have showed an increasing acceleration (Belcheir, \& Cucek, 2002; Özcan \& Yildırım, 2018). Distance learning programs are becoming more and more popular in the all over the world as technological developments create new opportunities. There are examples indicating the demand for distance learning opportunities in the world. For example, there are currently 85 accredited distance education institutions in the United States that offer various degree programs and some non-degree courses or programs. Moreover, there are more than 100,000 students at Hong Kong Open University in China, and 130,000 registered students at Universidad Nacional de Education in Spain. All of these numbers clearly show that distance learning practices have a global acceptance and popularity worldwide (Simonson, Smaldino, \& Zvacek, 2015). In Turkey as all over the world, due to the increasing use of internet technology, universities have shown interest in distance education applications. Many universities in Turkey offer distance education programs for graduate, undergraduate degree, and certificate programs (Özcan \& Yıldırım, 2018). These numbers are increasing day by day with the increase and proliferation of distance education.

Due to the increase in the number of students, the number of faculty members needed is also increasing in distance education. Instructor awareness, experience, and knowledge about distance education structure, and their contribution to distance education are crucial factors (Koloğlu, 2016). Koloğlu, (2016) investigated the factors that most encouraged faculty members to participate in distance education. These factors are reported as enabling communication technologies to be used effectively, providing access to a new audience that cannot reach on campus, providing leisure time thanks to the independence of the venue, and 
providing flexibility for the students.

Faculty members offering distance education courses also carry out courses in face-to-face education. Belcheir and Cucek, (2002) reported that faculty members spend more effort for development of distance education courses than face-to-face courses. Additionally, apart from the spent effort and time, financial difficulties are seen as a deterrent to the teaching of instructors in distance education. The perceptions of the instructors involved in distance education affect the quality of education. Belchier and Cucek (2002), in their study with 254 instructors teaching in distance education founded that the main motivators of instructors for offering course are new experience to learn, support for students, and administrators' request.

In distance education, instructors are one of the most important factors of students' motivation and success. Teaching staff have a central role in achieving the optimal level of education and achieving learning objectives in it. They are actively involved in the processes of design and delivery. Studies in the literature show that the roles of instructors in distance education have differences from face-to-face education. When the roles of instructors in distance education are examined in the literature, distance education demands specific roles as appropriate with its context although there might be similar roles with traditional education (Berge, 2008; Kara, 2018). The roles in the literature are defined and categorized with various terminologies such as content developer, guidance, technical consultant, manager, and so forth (Aydın 2005; Goodyear et al., 2001; Kara, 2018; Williams, 2003). For example, Berge (2008) described the roles of teachers in distance education as pedagogical, social, managerial, and technical. Similarly, Williams (2003) identified 13 instructors' role in distance education settings. Besides, Aydin (2005) conducted a study to determine the role and competence of the instructors in Turkish context. He concluded that the instructors have eight important roles in distance education. He labelled them as content expert, process facilitator, instructional designer, advisor, technologist, evaluator, material producer, and administrator. Moreover, According to İncik and Tanriseven (2012) the instructors have also academic roles in distance education. Some of those are to develop himself/herself in a professional way; to have a common attitude; to have a labor; to have a motivation; and to show a democratic approach. There are several example studies in the literature identifying instructor roles in distance education settings (e.g. Bawane \& Spector, 2009; Easton, 2003; Guasch, Alvarez, \& Espasa, 2010; Heuer \& King, 2004). The terminologies, as mentioned, classification, and prioritization of the defined roles might vary depending on the context and participant perspectives.

On the other hand, each of these instructor roles identified in the literature requires a single or multiple competencies, or some roles require some common competencies (Kara, 2018). Teacher competencies are defined as the knowledge, skills and attitudes that teachers need to have in order to perform the teaching profession effectively and efficiently (Turkish Education Association, 2009). In the previous studies, the competencies were classified according to utilization context, roles, or the characteristics of the skills (Bawane \& Spector, 2009). Whatever approach is adopted, in order to fulfill the above-mentioned roles, teaching staff should have these competencies. The relevant literature consists of several studies identifying and prioritizing instructor competencies in distance education (e.g. Aydin, 2005; Darabi, Sikorsky, \& Harvey, 2006; Goodyear et al., 2001; Varvel, 2007; Williams, 2003). According to Kara (2018), although various instructor roles and competencies can be found in the relevant literature, the priority or importance of each role and competency varies depending on the context of distance education. Aydın (2005) states that, instructors have to overcome certain potential barriers in distance learning processes to effectively create 
learning environments using technological tools. Therefore, they must have different qualifications than face-to-face educational environments.

Lecturing in distance education environment alone is not enough, instead teachers have many synchronous and asynchronous responsibilities. In order to increase the quality and efficiency in distance education, it is of great importance that the instructors are aware of these responsibilities. For this sort of awareness, continuous professional development of the instructors are a necessity for quality assurance. These programs are required to be focused on empowering and encouraging the instructors to be active learners so that they can take the responsibility of their own learning through the reflections on their practice by avoiding techno-centric and one-size-fits-all approaches (Baran, Correia, \& Thompson, 2011). For this reason, it is a determinant factor on the quality of distance education practices how instructors constructed their knowledge of teaching and learning at a distance. Specifically, how they constructed their knowledge about their roles and competencies in distance education drives their practices. In this context, the aim of this study is to reveal the conceptions and misconceptions of the instructors pertaining to their roles and competencies in distance education. The current study particularly sought to answer the following research questions:

- What are the conceptions of the instructors pertaining to their roles and competencies in distance education?

- What are the misconceptions of the instructors, if any, pertaining to their roles and competencies in distance education?

\section{Method}

\section{Research Design}

The current study aimed to explore instructor conceptions and misconceptions of their roles and competencies in distance education settings. Based on this aim, qualitative case study research design was employed. Creswell (2007, p.73) defines case study as a qualitative methodology to investigate an issue through one or multiple cases in a delimited system and describes it as a research design in which multiple sources of data are used to describe a case and case-based themes over time. The present study is an instrumental case study, in which a single case is selected and investigated (Cresswell, 2007, p.74). In this study, distance education context of a public university was chosen as the case and the role and competency conceptions of the instructors practicing in distance education programs of this university were investigated as the issue. Semi-structured interviews and observations were used in the study so as to describe the case in detail.

\section{Participants}

Typical case sampling strategy, a type of purposeful sampling strategies in qualitative inquiry, was selected to determine the participants. This means that the participant instructors are the typical representatives of the other instructors in the identified case since typical sampling strategy "highlights what is normal or average" (Miles \& Huberman, 1994, p.28). The participants of the current study are the nine instructors offering distance education courses at undergraduate and graduate levels. The participants have the titles of professor $(\mathrm{N}=2)$, assistant professor $(\mathrm{N}=1)$, and instructor $(\mathrm{N}=6)$. They deliver the courses in the distance education programs of classroom teaching, the internet and network technology, electrics, child development, elderly care, and medical documentation and secretariat. One of 
the instructors delivers Turkish language course in distance education programs, which is a common compulsory course in all programs. Four of them have a degree on education while the rest of them have the degrees from other disciplines. Their experience in teaching distance education range from one to six years. Considering these characteristics of the participants, the required variation in terms of teaching field, teaching level, educational background, and experience was provided so as to ensure that the participants are the typical instructors of distance education. The sample size was determined relying on the conceptual saturation in the qualitative data analysis. The participants were named from I1 to I9 to keep them anonym through these unique pseudonyms assigned to each of them.

\section{Context of the Study}

In Turkey, the courses in distance education programs are delivered as fully online via Learning Management Systems (LMS). However, face-to-face sessions are delivered in the courses requiring practice such as some courses in Electrics and Mechatronics programs. The instructors are assigned to the courses by the head of the departments. They are responsible for the design, delivery, and assessment of the courses. In the university where the study was conducted, instructional materials are delivered to students on the LMS as online in video and text-based formats. Synchronous course activities are conducted on the Web Conferencing System integrated to the LMS in the form of weekly lessons. All asynchronous course activities are similarly conducted on the LMS. The used LMS also have such components as forum, messaging tools, announcements, exams, and so forth. Traditional exams and alternative evaluation methods such as portfolio, projects, and collaborative or individual assignments can be used for evaluation. Yet, the mainstream way of evaluation is multiple choice exams. Students have to attend two exams per semester; a mid-term and a final exam. The mid-term exams are conducted as online on the LMS while final examinations are conducted on the campus as paper and pencil. The instructors in the target university have not participated in any sort of in-service trainings except the individual trainings on the LMS usage.

\section{Instruments}

The data were collected through semi-structured interviews and observations on the distance courses of the participants. Both interview and observation forms were developed by the researchers based on the relevant literature on instructor roles and competencies in distance education. The questions in the interview schedule were about the instructor roles and competencies. A total of 13 questions were asked. Both schedules were reviewed by the two professionals, having a doctoral degree, from the department of computer education and instructional technology and revised based on their recommendations.

\section{Data Collection Procedure}

The interviews and observations were conducted concurrently in the spring semester of 2018. Firstly, the identified instructors were invited for participation via phone calls by informing them about the purpose of the study. The interviews were conducted in their offices in diverse schools of the university upon their requests. The interviews were recorded with the permissions of the participants and then transcribed for analysis. The durations of the interviews ranged from 10 to 15 minutes. 


\section{Data Analysis}

The qualitative data were analysed in three phases; organization of the data, reduction of the data through coding, and representation of the data in terms of tables and discussion as described by Creswell (2007, p.148). These phases, as Creswell (2007, p.150) elaborated, were not linear, but rather create a spiral in an interrelated manner. In the first phase, the data were transcribed into the text format and each incident was named through the pseudonyms. In the second phase, the transcripts were numerous times read by the researchers. The data were reduced into the data segments by coding through constant comparison analysis method. The codes were interpreted relying on the field notes and the memos taken by the researchers during the data collection and analysis and their dimensions and properties. Hybrid naming was used to label the codes. In other words, the labels were derived both from the collected data and the relevant literature. Based on these interpretations, the codes were classified as the themes by comparing them within and between the incidents. In the final phase, the codes and themes were illustrated through the tables and described and discussed by paying special attention to the context because description of the study context has a key role in case studies (Creswell, 2007, p.151). Throughout the three phases of the data analysis, the researchers kept memoing and used them to refine the tentative codes and themes extracted from the data.

\section{Trustworthiness of the Study}

Trustworthiness of the study was ensured by following the guidelines of Lincoln and Guba (1985). Credibility was ensured through prolonged engagement of the researchers in the study context, triangulation, and peer debriefing. First of all, the researchers spent sufficient time in the study context so as to understand the setting and create the best rapport with the participants. Then, the interview data were triangulated through the observation on distance courses. Peer debriefing was also employed to avoid researchers' potential bias on the research problem. For this purpose, the data were coded by another professional of computer education and instructional technology, holding a doctoral degree in the same field, based on the guidelines of Garrison et al. (2006) on negotiated coding approach. An agreement percentage of 84.21 was achieved. As Garrison et al. (2006) described, the codes were actively discussed among the coders and a consensus was achieved on the final version of them. Transferability of the findings was provided through the in-depth descriptions of the codes and themes within the study context. Finally, as for confirmability, researchers adopted a reflective attitude toward the study problem throughout the study procedure.

\section{Findings}

The findings were classified under three main categories; conceptions of roles and competences, and misconceptions. For each theme, the frequency of the codes were presented. In addition, the descriptions of each code were supported with the quotations from the interviewee responses.

\section{Conceptions of Roles}

Instructor roles were defined in this study as the acts of the instructors that they play to deliver distance course. Two sub-themes were extracted from the participant responses. Their responses during the interviews pertaining to their roles were based on their experience in both face-to-face and distance education. 
Table 1. Role Conceptions of the Instructor Roles in Distance Education

\begin{tabular}{lll}
\hline \multicolumn{1}{c}{ Sub-Theme } & Conceptions of Roles & $\mathrm{f}$ \\
\hline \multirow{2}{*}{ Planning } & Environmental/Technical Planning & 3 \\
& Instructional Design & 3 \\
\cline { 2 - 3 } Course Delivery & Lecturing & 7 \\
& Evaluation & 3 \\
& Guidance & 3 \\
& Motivation & 2 \\
& Material Development & 2 \\
\hline
\end{tabular}

The first role conception of the instructors is planning. Planning covered environmental/technical planning and instructional design. The participants justified the need for planning by underlining the varying factors that might influence the synchronous lessons such as low student participation, low student motivation, and possible technical problems. Selecting the most appropriate synchronous lesson time is, for example, an action taken to improve student participation as part of the planning. An instructor, for instance, stated this role as follows:

"As an instructor, first of all, preparation of course settings... Taking the required actions by instructors... These are the fundamental responsibilities of an instructor. ...Besides, by distance education, we mean an approach in which we have limited interaction. But, when you achieve students integration into the system, you might have a more participatory and effective lesson. Thus, she/he should be prepared for this, too. " I4

The second role conception of the participants is delivery. Delivery sub-theme included lecturing, evaluation, guidance, motivation, and material development. The first role conception is lecturing synchronously. The mainstream way of teaching at a distance in this case is presentation in all courses followed by demonstration and practice in applied courses. In this regard, synchronous lecturing is perceived by the instructors as the most central role. Guidance code both includes the guidance on the distance education system and the guidance on the course. In spite of the availability of the guidance for the distance education system on student guides, the participants think that students still need instructor guidance. The other code is motivation. The instructors believe in that students at a distance need further motivation than the ones in face-to-face education considering that they are working adults and studying at a distance is more challenging than face-to-face education. The participants finally stated evaluation and material development as their usual roles. An instructor summarized below their delivery roles:

"Our top responsibility is to deliver the content of a course in conceptually exact manner. Then, the applications of them... I mean supporting understanding through both visual and experiments. Even, physically conducting these during the finals when students are here..." I9

\section{Conceptions of Competencies}

The instructor responses indicated that there are three important competencies required for distance education. These competencies are Information and Communication Technology (ICT) competency, Communication skills, and Subject Expertise as given at Table 2. 
Table 2. Conceptions of the Instructor Competencies in Distance Education

\begin{tabular}{ll}
\hline Conceptions of Competencies & f \\
\hline ICT Competency & 5 \\
Communication Skills & 3 \\
Subject Expertise & 2 \\
\hline
\end{tabular}

The most commonly stated competency by the instructors is ICT competency. They believe in that ICT competency is a survival and the most fundamental competency to deliver distance courses. By ICT competency, they mostly referred to the required knowledge and skills for Learning Management System (LMS) usage. An instructor explained the need for this competency as follows:

"Technology, first of all, is important. Entering a course by accessing to the site (LMS) by an instructor is quite important. He/she is required to be able to enter the system. She/he is required to be able to change lesson times as needed. He/she is required to be able to answer the questions of the students. He/she is required to have a technological background at a certain level. " $\mathrm{I} 3$

The secondly stated competency is communication skills. Some of the instructors have a thought that this competency is a requirement so as to facilitate interaction process in distance education settings considering communication challenges they faced. Subject expertise is the last competency stated by some of the interviewees. An instructor explained both of the competencies as follows:

"I think they, firstly, need to have good communication skills. All in all, knowledge sharing with the students is conducted via communication. Communication is the first. I think competency in his/her field is the second." I5

\section{Misconceptions}

The participant responses showed that instructors have some misconceptions regarding distance education. A total of six misconceptions were extracted from the interviewee responses. These misconceptions are presented in Table 3 as follows. Based on the participants' responses during the interviews, it was concluded that the instructors base these misconceptions on their experience in both face-to-face and distance education. The findings regarding the misconceptions further showed that they constructed the misconceptions through their trial-and-error approach since they learned how to practice in distance education settings by their own efforts.

Table 3. Misconceptions of Instructors in Distance Education

\begin{tabular}{ll}
\hline Misconceptions & f \\
\hline Use of the Same materials with Face-to-face Education & 8 \\
Sufficient Materials & 7 \\
No Role for Interaction among Students & 7 \\
Ineffectiveness of Distance Education & 6 \\
Having the Same Roles with Face-to-face Education & 4 \\
Impossibility of Distance Collaboration among Students & 3 \\
\hline
\end{tabular}

The most commonly observed misconception regarding distance education is the thought that the same materials with face-to-face education are used. The participants stated almost the 
similar thoughts in this regard. Only one of them stated that she uses more visuals so as to facilitate student understanding. In this respect, the use of the same materials imply the second misconception that the materials they used in distance education, also they use them in face-to-face education, is sufficient for distance education. The observations on distance courses revealed that they all use text-based materials without any or limited guidance or directions for supporting student autonomy. Similarly, the materials also lack of interactive properties. Even an instructor stated that she uses more detailed materials in face-to-face education and limited materials in distance education. An instructor stated both of these misconceptions as follows:

\begin{abstract}
"Same. I use exactly the same (materials in both face-to-face and distance education). ...There is no need for difference between them. The topics are the same. If we share videos to facilitate student understanding in distance education, we even show them (in face-to-face education)."I9
\end{abstract}

Another misconception of the instructors is that they think that they do not have a role for interaction among students. The participant instructors stated that the existing interaction among students are adequate and there is no need for them to spend any effort to encourage or improve this interaction. The statements of the participants supporting this misconceptions is as follows:

"We do not need to do it. They (students) already interact with each other. They have their own groups. They are in contact with each other for the courses." I5

The next misconceptions is the participant instructors' belief that distance education is ineffective. In fact, this is a result of the other misconceptions. Some of the instructors think distance education ineffective because of the communication problems or because some of them believe in that it is impossible to interact with students in distance education as do they in face-to-face education. For example, a participant think that distance education is ineffective because of the communication limitations and they state the similar ideas as follows:

"I do not think that it has the same effect ratio. Communication factor with our students is one-way in distance education. I do not think that it is so effective." I2

The belief that they have the same roles with face-to-face education is the other misconception of the instructors. The instructors think they have the same roles in both distance education and face-to-face education such as delivering synchronous lessons and evaluation. This misconception might be observed in an instructor's statement below:

"As I said earlier, all of them are the same. Whatever instructional responsibilities are in face-to-face education is required to be the same. In addition to this, communication problems are the responsibility of an instructor. She/he needs to do recovery process." I1

The final misconception of the instructors is about online collaboration. Some of them believe in that online collaboration is impossible. They think that the geographical distance makes collaborative activities impossible since collaboration requires physical meetings. For this reason, they stated that they prefer individual activities, instead. For example, an instructor stated her thoughts on online collaboration as follows: 
"It is a problem that they meet, they contact the by sharing responsibilities from various cities. For this reason, I avoid assigning collaborative works." I2

\section{Discussion}

This study aimed to investigate conceptions and misconceptions of the instructors in term of their roles and competencies in distance education. The findings revealed three themes; namely, conceptions of roles, competencies, and misconceptions.

The first theme created is the conceptions of their roles. In terms of their roles, the findings indicated that the participant instructors have very broad conceptions of their roles based on both their experience in face-to-face and distance education. Planning was particularly underlined by them mainly due to the complexity, challenges, and uncertainties, for which they need to spend more effort in distance education settings than face-to-face education to deal with them. The planning covered the issues of configuration of physical environment, and technological tools, and instructional design for improving student participation such as setting the optimal synchronous lesson times and the most appropriate delivery method, but not design for materials. The second role is course delivery. They perceive this role same as the one in face-to-face education with a difference that technology is used for delivery. The roles regarding planning and course delivery are underlined by the previous studies defining instructor roles in distance education with diverse terms (e.g. Aydın, 2005; Bawane \& Spector, 2009; Varvel, 2007; Williams, 2003). However, the findings of the present study indicated that the instructors do not pay attention on other roles such as social, managerial or advisor roles. The reason behind the generality of instructor perceptions on their roles is likely the lack of their knowledge and skills regarding distance education and its pedagogy.

The second theme is the conceptions of their competencies. The competency conceptions of the instructors are very broad. The competencies they stated are Subject Expertise, ICT competency, and Communication skills. Subject expertise is a natural conception expected from all instructors regardless of the delivery medium. On the other hand, the instructors believe in that distance education demands the competencies of ICT and communication skills so as to deal with all sort of instructional problems and communication challenges specific to distance education settings. Similar to the instructor roles, the literature on instructor competencies in distance education previously underlined the ones found out in the present study with various terms (e.g. Guasch et al., 2010; Darabi et al., 2006; Varvel, 2007; Williams, 2003). The findings of the present study illustrated that the instructors constructed their competency conceptions based on their experience and challenges in their own practices. The final theme created is the misconceptions of the instructors. The findings of the study revealed that the instructors filled in the blanks in their broad conceptions of the roles and competencies with the misconceptions that they constructed based on their experience in their trial-and-error efforts. The observed misconceptions are the belief that use of same materials with face-to-face education, sufficient materials, lack of role for interaction among students, ineffectiveness of distance education, having the same roles with face-to-face education, and impossibility of online collaboration among students. These findings confirmed the notion that learning by trial-and-error causes the instructors to have negative conclusions about distance education (Fang, 2007). Furthermore, as pointed out by Baran, et al. (2011), a techno-centric approach with a perspective of one-size-fits-all causes the replication of the traditional approaches in distance education. The use of the same materials and efforts to perform the same roles in both distance and face-to-face education, for example, are the indicators of the replication of the traditional approaches in distance education. As stated 
earlier for their conceptions, these misconceptions are also the natural result of the lack of prerequisite knowledge and skills for the instructors to practice in distance education context. Therefore, the study findings suggest continuous professional development starting prior to acting in distance education because the more the instructors engaged in professional development activities, the more they have awareness (Gonzalez-Sanmamed et al., 2014). The findings also imply that the professional development programs are required to be based on the notion that a critical reflection and practice of the instructors so as to transform their teaching in distance education is a necessity by adopting them as adult learners (Baran, et al., 2011). Therefore, the findings identified in this study suggest active reflection of the instructors on their conceptions and practices for improvement.

\section{Conclusion}

This case study revealed the conceptions of the instructors in terms of their roles and competencies and misconceptions regarding distance education. Their conceptions of roles and competencies are based on their experience in both face-to-face and distance education. This base unsurprisingly leads to misconceptions regarding teaching in distance education. The main reason behind the instructor conceptions on their roles and competencies and misconceptions is the unavailability of professional development programs and learning by trial-and-error, consequently. The study findings showed that particularly the lack of prerequisite knowledge regarding distance education pedagogy causes instructor misconceptions by basing their conceptions on face-to-face education. For this reason, instructor support for both professional development and their active reflection on their meaning making process is a continuing necessity for the construction of their conceptions by encouraging them to avoid the frameworks of the traditional approaches.

\section{Recommendations for Future Research and Practice}

The study has several limitations. First of all, it was conducted with the participation of the instructors in a university. Multiple case studies might be conducted in different contexts with multiple stakeholders. Secondly, the findings of the study are descriptive. The prescriptive studies focusing on the design for professional development studies aiming to improve teaching practices and to transform instructor conceptions might be conducted based on the needs assessment. Particularly, the study findings suggest further research on instructor reflections on their conceptions and practices as they participate in professional development studies from a critical perspective.

The study certainly has implications for practice. Firstly, trainings for instructors, particularly pertaining to distance education processes and pedagogy, are required to be provided before instructor recruitment so as to base their meaning making process on the correct conceptualizations. The professional development efforts in various fields such as pedagogy, andragogy, technology integration, and social aspects are recommended to be continuously available for instructors. Instructor reflections on their practices are also a recommendation of this study for them and professionals to transform the practices and conceptions.

\section{References}

Aydın, C. H. (2005). Turkish mentors' perception of roles, competencies and resources for online teaching. Turkish Online Journal of Distance Education, 6(3), 58-80. 
Baran, E., Correia, A. P., \& Thompson, A. (2011). Transforming online teaching practice: Critical analysis of the literature on the roles and competencies of online teachers. Distance Education, 32(3), 421-439.

Bawane, J., \& Spector, J. M. (2009). Prioritization of online instructor roles: implications for competency-based teacher education programs. Distance Education, 30(3), 383-397.

Belcheir, M.J. \& Cucek, M. (2002). Faculty perceptions of teaching distance education courses. Research Report. Boise State Üniversitesi. Retrieved from: https://files.eric.ed.gov/fulltext/ED480925.pdf

Berge, Z. L. (2008). Changing instructor's roles in virtual worlds. Quarterly Review of Distance Education, 9(4), 407-414.

Creswell, J. W. (2007). Qualitative Inquiry and Research Design: Choosing among Five Approaches ( $2^{\text {nd }}$ Ed.). Sage.

Darabi, A. A., Sikorski, E. G., \& Harvey, R. B. (2006). Validated competencies for distance teaching. Distance Education, 27(1), 105-122.

DEAC, Distance Education Accrediting Commission. (2017). Directory of accredited institutions. Retrieved from https://www.deac.org/Student-Center/Directory-OfAccredited-Institutions.aspx

Easton, S. S. (2003). Clarifying the instructor's role in online distance learning. Communication Education, 52(2), 87-105.

Fang, B. (2007). A performance-based development model for online faculty. Performance Improvement, 46(5), 17-24.

Garrison, D. R., Cleveland-Innes, M., Koole, M., \& Kappelman, J. (2006). Revisiting methodological issues in transcript analysis: Negotiated coding and reliability. The Internet and Higher Education, 9(1), 1-8.

González-Sanmamed, M., Muñoz-Carril, P. C., \& Sangrà, A. (2014). Level of proficiency and professional development needs in peripheral online teaching roles. The International Review of Research in Open and Distributed Learning, 15(6), 162-187.

Goodyear, P., Salmon, G., Spector, J. M., Steeples, C., \& Tickner, S. (2001). Competences for online teaching: A special report. Educational Technology Research and Development, 49(1), 65-72.

Gök B. (2007) Uzaktan ĕgitimde görev alan öğretim elemanlarının uzaktan eğitim algısı. Unpublished master's thesis, Gazi University, Ankara.

Guasch, T., Alvarez, I., \& Espasa, A. (2010). University teacher competencies in a virtual teaching/learning environment: Analysis of a teacher training experience. Teaching and Teacher Education, 26(2), 199-206.

Gülbahar, Y. (2009). E-ögrenme. Ankara: Pegem Yayıncılık.

Heuer, B. P., \& King, K. P. (2004). Leading the Band: The role of the instructor in online learning for Educators. The Journal of Interactive Online Learning, 3(1), 1-11.

Kara M. (2018). Influential factors on faculty performance in distance education. Unpublished Doctoral Dissertation, Middle East Technical University, Ankara.

Kaya, Z. (2002). Uzaktan Ĕ̈itim. Pegem Yayıncılık.

Koloğlu T. F. (2016) Öğretim elemanlarının uzaktan eğitime bakış açıları ve hazırbulunuşluklarl: Ordu üniversitesi örneği. Unpublished Master's Thesis, Afyon Kocatepe University, Afyonkarahisar.

Lincoln, Y. S. \& Guba, E. G. (1985). Naturalistic inquiry. Sage.

İncik, E. Y., \& Tanrıseven, I. (2012). Eğitim fakültesi öğretim elemanlarının ve öğretmen adaylarının öğrenci merkezli eğitime ilişkin görüşleri (Mersin üniversitesi örneği). Mersin Üniversitesi Eğitim Fakültesi Dergisi, 8(3), 172-184.

Miles, M. B. \& Huberman, A. M. (1994). Qualitative Data Analysis: An Expanded Source Book ( $2^{\text {nd }}$ Ed. $)$. Sage. 
Moore, M. G. \& Kearsley, G. (2004). Distance Education: A Systems View (2nd Ed.). USA: Wadsworth Publishing.

Özcan, H. \& Yıldırım, S. (2018). Administrators' perceptions of motives to offer online academic degree programs in universities. International Review of Research in Open and Distributed Learning, 19 (1), 327-341.

Simonson, M., Smaldino, S., \& Zvacek, S. (2015). Teaching and learning at a distance: Foundations of distance education (6th ed.) Charlotte, NC: Information Age.

Turkish Education Association (2009). Öğretmen yeterlikleri özet rapor: Öğretmene yatırım, geleceğe atılım. Retrieved from ted.org.tr.

Umurhan, H. (2014). Öğretim elemanlarını uzaktan eğitime teşvik eden unsurlar: Gazi üniversitesi örneği. Unpublished Master’s Thesis. Gazi University, Ankara.

Varvel, V. E. (2007). Master online teacher competencies. Online journal of distance learning administration, 10(1), 1-41.

Williams, P. E. (2003). Roles and competencies for distance education programs in higher education institutions. The American Journal of Distance Education, 17(1), 45-57. 